\title{
Effect of Open-Heart Surgery on the Body Composition of Infants and Young Children
}

\author{
YVES W. BRANS, ${ }^{(2)}$ HARRY S. DWECK, HOWARD B. HARRIS, GRANT V. S. PARR, \\ PENRHYN E. BAILEY, JOHN W. KIRKLIN, AND GEORGE CASSADY \\ Perinatal Research Laboratory, Division of Perinatal Medicine, Department of Pediatrics and the Division of \\ Cardiovascular Surgery, Department of Surgery, University of Alabama, Birmingham, Alabama, USA
}

\begin{abstract}
Summary
Body water content and distribution were determined in 16 children aged 2 wk to 28 months before and after open-heart surgery for correction of congenital cardiac defects. Operative procedures were performed using hypothermia and extracorporeal oxygenation. On the day before and the day after surgery, total body water was estimated as the antipyrine space (APS); extracellular water, as the corrected bromide space (CBS), and plasma volume, as the 10-min T-1824-albumin space. Intracellular water (ICW) was assumed to be the difference between APS and CBS; interstitial water was calculated from plasma volume and CBS. Before initiation and after completion of extracorporeal circulation, a pectoral muscle biopsy was performed, and a blood sample was obtained. Muscle total water (TW) content was determined by desiccation, extracellular water (ECW) was estimated as the corrected chloride space, and ICW was assumed to be the difference between TW and ECW. Plasma sodium, potassium, chloride, glucose, and osmolality contents were determined by routine methods. All studies were not completed in all patients.

Although APS and CBS increased in eight of 11 children, mean APS ( \pm S.E.) before and after surgery $(662 \pm 28.0$ versus $714 \pm$ $37.2 \mathrm{ml} / \mathrm{kg})$ and mean CBS $(335 \pm 30.5$ versus $358 \pm 15.5 \mathrm{ml} / \mathrm{kg})$ were not statistically different. Mean ICW changed neither in relation to body weight $(328 \pm 28.0$ versus $355 \pm 34.2 \mathrm{ml} / \mathrm{kg})$ nor in relation to APS (ICW/APS ratio $=0.48 \pm 0.040$ versus 0.49 $\pm 0.010)$. Neither mean PV (54 \pm 4.0 versus $56 \pm 2.8 \mathrm{ml} / \mathrm{kg})$ nor mean blood volume $(92 \pm 5.4$ versus $90 \pm 5.5 \mathrm{ml} / \mathrm{kg})$ changed significantly. Mean interstitial water increased by 9 to $68 \%$ over preoperative values in all but one patient $(238 \pm 10.4$ versus 305 $\pm 13.4 \mathrm{ml} / \mathrm{kg} ; P<0.01$ ).
\end{abstract}

Muscle composition was not affected by the procedure. Mean TW was $79 \pm 1.3 \mathrm{ml} / 100 \mathrm{~g}$ before extracorporeal circulation and $78 \pm 0.8 \mathrm{ml} / 100 \mathrm{~g}$ afterwards whereas $\mathrm{ECW}$ averaged $32 \pm 4.4$ and $36 \pm 3.4 \mathrm{ml} / 100 \mathrm{~g}$, and ICW averaged $48 \pm 4.6$ and $42 \pm 2.9$ $\mathrm{ml} / 100 \mathrm{~g}$. Mean $\mathrm{ICW} / \mathrm{TW}$ ratios were $0.60 \pm 0.055$ and $0.54 \pm$ $0.040 \mathrm{ml} / 100 \mathrm{~g}$.

Although mean plasma sodium $(142 \pm 3.5$ versus $139 \pm 2.4 \mathrm{mEq} /$ liter) and potassium $(3.3 \pm 0.16$ versus $3.6 \pm 0.15 \mathrm{mEq} /$ liter $)$ concentrations did not change appreciably during extracorporeal circulation; mean plasma chloride content decreased $(108 \pm 2.9$ versus $100 \pm 2.0 \mathrm{mEq} /$ liter; $P<.002$ ). Plasma glucose averaged $60 \mathrm{mg} / \mathrm{dl}$ more at completion of the procedure, increasing from a mean of $223 \pm 25.6 \mathrm{mg} / \mathrm{dl}$ to a mean of $283 \pm 5.3 \mathrm{mg} / \mathrm{dl}(P<$ 0.05). Plasma osmolality increased in five of eight children, but mean osmolalities were similar before and after extracorporeal circulation ( $301 \pm 8.9$ versus $303 \pm 5.4 \mathrm{mOsm} / \mathrm{kg})$.

These data suggest that a child's organism does not react complacently to the invasive procedures associated with openheart surgery. Further research into effects of these procedures and into means of minimizing undesirable homeostatic disturbances is warranted.

\section{Speculation}

Body composition of adult patients has been shown to be acutely altered by open-heart surgery with hypothermia and extracorporeal circulation. Our data suggest that similar changes occur in young children who are subjected to these procedures. Because small children, especially those afflicted with major congenital defects, have limited homeostatic capabilities, the risk of these disturbances becoming life-threatening is increased. Means of minimizing them need be devised.

Cardiopulmonary bypass and moderate hypothermia have been shown to acutely alter the body composition of adult patients undergoing open-heart surgery $(2,12)$. Total body water and intracellular water remain stable, but extracellular water increases, particularly in the interstitial compartment. Disturbances of body fluids and body composition have received limited attention in children with cardiac disorders $(8,11)$. Although clinical observations of edema and electrolyte disturbances are frequent in the period after repair of congenital heart malformations in infants and children, changes in body composition have not been documented. Changes in body composition may be further affected by the profound hypothermia and low flow states, even total circulation arrest used in children $(1,7)$. This study was designed to identify changes in body composition resulting from intracardiac surgery in children less than $2 \frac{1}{2}$ years old.

\section{MATERIALS AND METHODS}

Parental permission was obtained to study body composition 1 day before and 1 day after cardiac surgery in 16 infants and young children ranging in age from 2 wk to 28 months (Table 1). Most common surgical diagnoses were ventricular septal defect (six patients), transposition of the great arteries (five patients) and pulmonary stenosis (two patients). Total anomalous venous connection, tetralogy of Fallot, and double outlet right ventricle were each repaired in one patient. Males and females were equally represented. All but three patients had weights below the 10th percentile for age and sex (10), and 10 had weights below the third percentile.

One day before surgical repair, a polyethylene catheter was placed through a greater saphenous vein and advanced into the inferior vena cava. This procedure was performed in an operating room using strict aseptic technique and local Xylocaine $(1 \mathrm{~g} / \mathrm{dl})$ (Lidocaine-HCl) (16) not exceeding $5 \mathrm{ml}$ in volume. All indicator injections and sample withdrawals were made through this catheter after adequate flushing.

Cardiac surgical repairs were performed using extracorporeal circulation and pediatric bubble oxygenators (Bentley Q 130) (17) primed with heparinized whole blood diluted to a hematocrit of $30 \%$ (7). The priming solution contained sodium (138 mEq/liter), 
Table 1. Description of the study population

\begin{tabular}{|c|c|c|c|c|c|}
\hline Patient & Sex & Race & $\begin{array}{l}\text { Age } \\
(\mathrm{mos})\end{array}$ & $\begin{array}{l}\mathrm{Wt} \\
(\mathrm{kg})\end{array}$ & Diagnosis \\
\hline 1 & $\mathrm{M}$ & W & 8 & 5.5 & Ventricular septal defect \\
\hline 2 & $\mathrm{~F}$ & W & 4 & 4.9 & $\begin{array}{l}\text { Transposition of the great } \\
\text { arteries }\end{array}$ \\
\hline 3 & $\mathrm{~F}$ & W & 4 & 6.8 & Tetralogy of Fallot \\
\hline 4 & M & W & 10 & 6.8 & $\begin{array}{l}\text { Transposition of the great } \\
\text { arteries }\end{array}$ \\
\hline 5 & $\mathrm{~F}$ & W & 10 & 7.2 & $\begin{array}{l}\text { Transposition of the great } \\
\text { arteries }\end{array}$ \\
\hline 6 & $\mathrm{~F}$ & B & 0.5 & 2.4 & $\begin{array}{l}\text { Total anomalous venous } \\
\text { connection }\end{array}$ \\
\hline 7 & $\mathbf{M}$ & W & 28 & 14.0 & Pulmonary stenosis \\
\hline 8 & $\mathbf{M}$ & W & 10 & 8.9 & Ventricular septal defect \\
\hline 9 & $M$ & B & 8 & 6.5 & Ventricular septal defect \\
\hline 10 & $\mathrm{~F}$ & B & 14 & 9.0 & Ventricular septal defect \\
\hline 11 & $\mathrm{~F}$ & $\mathrm{~W}$ & 22 & 8.2 & $\begin{array}{l}\text { Transposition of the great } \\
\text { arteries }\end{array}$ \\
\hline 12 & M & W & 12 & 7.4 & $\begin{array}{l}\text { Double outlet right ventri- } \\
\text { cle }\end{array}$ \\
\hline 13 & $F$ & W & 3 & 4.8 & Ventricular septal defect \\
\hline 14 & $M$ & W & 5 & 6.2 & $\begin{array}{l}\text { Transposition of the great } \\
\text { arteries }\end{array}$ \\
\hline 15 & $\mathrm{~F}$ & B & 6 & 5.0 & Ventricular septal defect \\
\hline 16 & $\mathbf{M}$ & W & 3 & 4.7 & Pulmonary stenosis \\
\hline
\end{tabular}

potassium $(3.1 \mathrm{mEq} /$ liter $)$, and glucose $(1060 \mathrm{mg} / \mathrm{dl})$; its osmolality was $320 \mathrm{mOsm} / \mathrm{kg}$. Profound hypothermia with nasopharyngeal temperatures of 20 to $24^{\circ} \mathrm{C}$ was used in combination with periods of low flow $\left(0.5 \mathrm{liter} / \mathrm{min} / \mathrm{m}^{2}\right)$ or total circulatory arrest (7). Surface cooling was not used. Postoperatively, blood or packed red blood cells were administered in quantities sufficient to maintain left atrial pressure about $14 \mathrm{~mm} \mathrm{Hg} \mathrm{(13).} \mathrm{Fluid} \mathrm{and} \mathrm{electrolyte}$ administration over the first $24 \mathrm{hr}$ after operation was limited to $750 \mathrm{ml}$ of $10 \mathrm{~g} / \mathrm{dl}$ dextrose in sodium chloride $(0.3 \mathrm{~g} / \mathrm{dl})$ plus 30 $\mathrm{mEq}$ of potassium chloride per square meter of patient body surface area.

Water content of the various body compartments was determined 1 day before and 1 day after surgery. APS (antipyrine space) (total body water) and CPS (corrected bromide space) (extracellular water) were estimated simultaneously after intravenous injection of a sterile solution containing sodium bromide (5 $\mathrm{g} / \mathrm{dl})(8)$ and antipyrine (1-phenyl-2,3-dimethylpyrazolone-5-one) $(0.5 \mathrm{~g} / \mathrm{dl})(19)$ in sodium chloride $(0.9 \mathrm{~g} / \mathrm{dl})$. The exact amount of marker injected was calculated from the measured concentration of the injectate, the weight of injectate administered, and the specific gravity of the injectate. An average of $11 \mathrm{mg} / \mathrm{kg}$ (range, 7 to $14 \mathrm{mg} / \mathrm{kg}$ ) of antipyrine and $90 \mathrm{mg} / \mathrm{kg}$ (range, 71 to $105 \mathrm{mg}$ / $\mathrm{kg}$ ) of bromide were injected. Antipyrine concentrations were determined in triplicate on the injectate solution and on plasma samples obtained before injection of the marker and 1 and $3 \mathrm{hr}$ after injection (9). APS was estimated from zero-time dilution as extrapolated from the $1-$ and 3 -hr postinjection concentrations using the least-squares method for estimating the best fit of these points to a straight line:

$$
\text { APS }=\frac{\text { amount of antipyrine injected }}{\text { zero-time plasma antipyrine concentration }} \times 0.934
$$

where 0.934 is a correction factor for the proportion of water in plasma (4). Bromide concentrations were determined in triplicate on the injectate solution and on plasma samples obtained before and $1 \mathrm{hr}$ after injection of the marker (15). The CPS was calculated by the following formula:

$$
\mathrm{CPS}=\frac{\text { amount of bromide injected }}{1 \mathrm{hr} \text { plasma bromide concentration }} \times \frac{0.90}{0.95 \times 0.934}
$$

where 0.90 corrects for an estimated $10 \%$ intracellular bromide (6), 0.95 corrects for the Donnan equilibrium, and 0.934 corrects for the proportion of water in plasma. Intracellular water was assumed to be the difference between APS and CBS. Plasma volume was estimated after intravenous injection of a sterile solution containing T-1824 (Evans Blue) ( $1 \mathrm{~g} / \mathrm{dl})(20)$ and sodium chloride $(0.9 \mathrm{~g} / \mathrm{dl})$. The exact amount of dye injected was calculated from the measured concentration of the injectate, the weight of injectate administered and the specific gravity of the injectate. Concentrations of T-1824 were determined in triplicate on the injectate solution and on plasma samples obtained before and exactly 10 min after injection of the marker (3). Plasma volume was calculated from the formula:

$$
\text { Plasma volume }=\frac{\text { amount of } \mathrm{T}-1824 \text { injected }}{10 \text { min plasma } \mathrm{T}-1824 \text { concentration }}
$$

Hematocrits were determined in duplicate on the pre-injection blood samples in $75 \mathrm{~mm}$ long and $1 \mathrm{~mm}$ wide (internal diameter) capillary tubes spun at $11,500 \mathrm{rpm}$ for $5 \mathrm{~min}$ in a microhematocrit centrifuge. No corrections were made for trapped plasma on body/venous hematocrit ratio. Blood volume was calculated as follows:

$$
\text { Blood volume }=\frac{\text { plasma volume }}{100-\text { hematocrit }(\%)} \times 100
$$

Interstitial water volume was calculated as the difference between corrected bromide space and plasma volume. All volumes were expressed in $\mathrm{ml} / \mathrm{kg}$ body weight.

Samples of heparinized blood were obtained immediately before connecting the patient to the extracorporeal pump and immediately after disconnecting the pump. Duplicate determinations of plasma sodium and potassium (flame photometry), chloride (perborate-oxydation in a Buchler chloridometer (21), glucose (glucose oxydase), and osmolality (freezing point depression) contents were made.

Small samples of pectoral muscle (range, 13.3 to $15.3 \mathrm{mg}$ ) were obtained immediately before connecting and immediately after disconnecting the extracorporeal pump. The samples were blotted once with a layer of gauze, without applying any pressure, to remove excessive moisture and blood, immediately placed in a preweighed glass vial and weighed to the nearest $0.01 \mathrm{mg}$. The samples were then desiccated to constant weight in an oven at $100^{\circ} \mathrm{C}$ and then bathed in petroleum-ether with frequent changes of solvent until the supernatant was clear. The remaining fat-free dry solids were ground to powder for duplicate determinations of chloride content (perborate-oxydation in a Buchler chloridometer). Total water content was calculated as the difference between sample weights before and after desiccation. Extracellular water content was estimated as the chloride space, assuming that $90 \%$ of total chlorides were located extracellularly (6), according to the formula:

Corrected chloride space $=\frac{\text { amount of chloride in sample }}{\text { plasma chloride concentration }} \times 0.90$

Intracellular water content was assumed to be the difference between total and extracellular water contents. All volumes were expressed in $\mathrm{ml} / 100 \mathrm{~g}$ of muscle (wet weight).

Statistical analysis between pre- and postintervention values was performed by means of Student's paired $t$ test.

\section{RESULTS}

Pre- and postsurgery antipyrine and bromide dilution studies were performed in 11 children (Fig. 1). Although antipyrine space (APS) and CPS increased in eight of 11 children, postoperative volumes were not statistically different from pre-operative volumes. Mean APS ( \pm S.E.) was $662 \pm 28.0 \mathrm{ml} / \mathrm{kg}$ before and 714 $\pm 37.2 \mathrm{ml} / \mathrm{kg}$ after surgery. Mean corrected bromide space was 

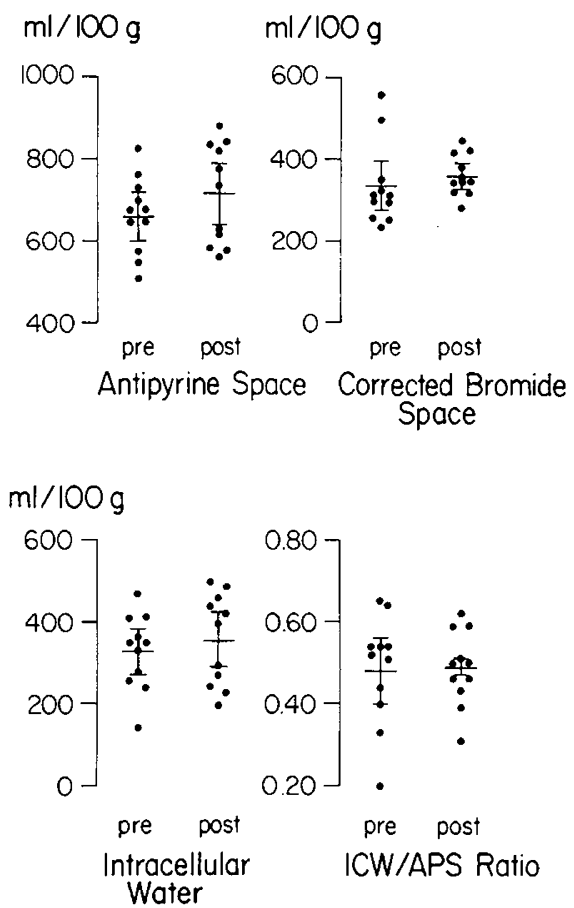

Fig. 1. Antipyrine space, corrected bromide space, intracellular water, and intracellular water/antipyrine space ratio before and after surgery. Mean \pm 2 S.E. superimposed on the range of individual values.

$335 \pm 30.5 \mathrm{ml} / \mathrm{kg}$ before and $358 \pm 15.5 \mathrm{ml} / \mathrm{kg}$ after surgery. Intracellular water changed neither in relation to body weight nor in relation to APS (intracellular water/APS ratio). Mean intracellular water were $328 \pm 28.0$ and $355 \pm 34.2 \mathrm{ml} / \mathrm{kg}$, respectively, before and after surgery whereas mean intracellular water/APS were $0.48 \pm 0.040$ and $0.49 \pm 0.010$.

Pre- and postsurgery T-1824 dilution studies were completed in nine patients (Fig. 2). Neither plasma nor blood volume changed significantly. Mean plasma volume was $54 \pm 4.0 \mathrm{ml} / \mathrm{kg}$ before operation and $56 \pm 2.8 \mathrm{ml} / \mathrm{kg}$ afterwards. Mean blood volume were $92 \pm 5.4 \mathrm{ml} / \mathrm{kg}$ and $90 \pm 5.5 \mathrm{ml} / \mathrm{kg}$, respectively. All nine of these patients also had corrected bromide space determinations. Interstitial water increased by 9 to $68 \%$ (mean, 30\%) over preoperative volume in all but one patient $(P<0.01)$ (Fig. 3). Mean interstitial water was $238 \pm 10.4 \mathrm{ml} / \mathrm{kg}$ before and $305 \pm 13.4 \mathrm{ml} /$ $\mathrm{kg}$ after surgery.

To differentiate potential changes associated with extracorporeal circulation and hypothermia alone from those associated with the total effects of surgery as well as pre- and postoperative events, a pectoral muscle biopsy was performed at initiation and completion of extracorporeal circulation in seven children (Fig. 4). Differences in muscle water content and distribution were not statistically significant. Total water content of muscle averaged $79 \pm$ $1.3 \mathrm{ml} / 100 \mathrm{~g}$ before and $78 \pm 0.8 \mathrm{ml} / 100 \mathrm{~g}$ after extracorporeal circulation. Muscle extracellular water averaged $32 \pm 4.4 \mathrm{ml} / 100$ $\mathrm{g}$ before and $36 \pm 3.4 \mathrm{ml} / 100 \mathrm{~g}$ after. Mean intracellular water was $48 \pm 4.6$ and $42 \pm 2.9 \mathrm{ml} / 100 \mathrm{~g}$, respectively, and mean intracellular/total water ratios were $0.60 \pm 0.055$ and $0.54 \pm 0.040$.

Plasma electrolyte contents were measured before and after extracorporeal circulation in eight patients (Table 2). Plasma sodium and potassium did not change appreciably. Natremia averaged $142 \pm 3.5 \mathrm{mEq} /$ liter before pump and $139 \pm 2.4 \mathrm{mEq} /$ liter afterwards whereas kalemia averaged $3.3 \pm 0.16$ and $3.6 \pm$ $0.15 \mathrm{mEq} /$ liter. Chloride concentrations, on the other hand, were significantly lower upon completion of the procedure $(P<0.002)$, declining from a mean of $108 \pm 2.9 \mathrm{mEq} /$ liter before to a mean of $100 \pm 2.0 \mathrm{mEq} /$ liter after pump. Plasma glucose content was already elevated before connection of the pump $(223 \pm 25.6 \mathrm{mg} /$ dl) and increased further to a mean of $283 \pm 5.3 \mathrm{mg} / \mathrm{dl}(P<0.05)$ as a result of the priming solution in the pump oxygenator.

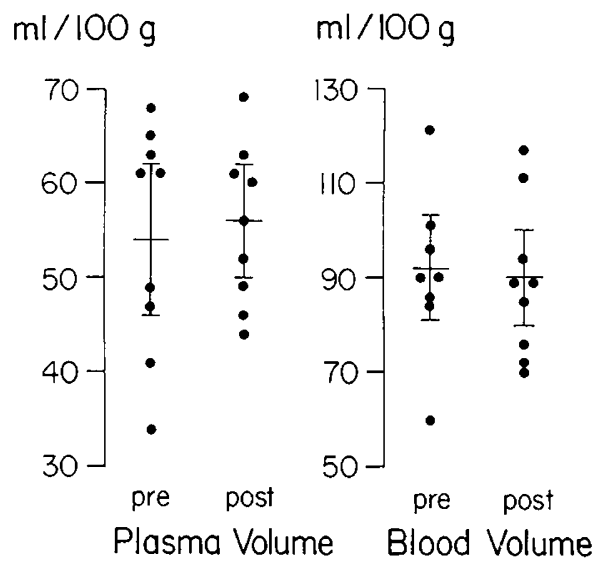

Fig. 2. Plasma and blood volume before and after surgery. Mean \pm 2 S.E. superimposed on the range of individual values.

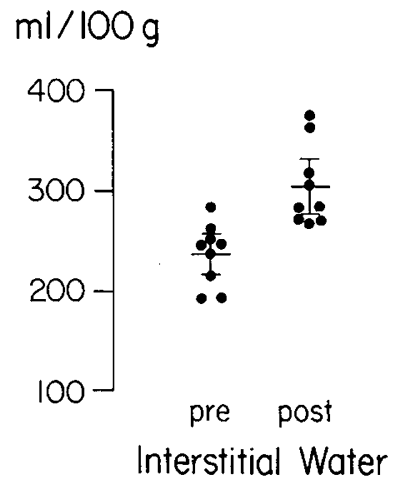

Fig. 3. Interstitial water volume before and after surgery. Mean \pm 2 S.E. superimposed on the range of individual values.
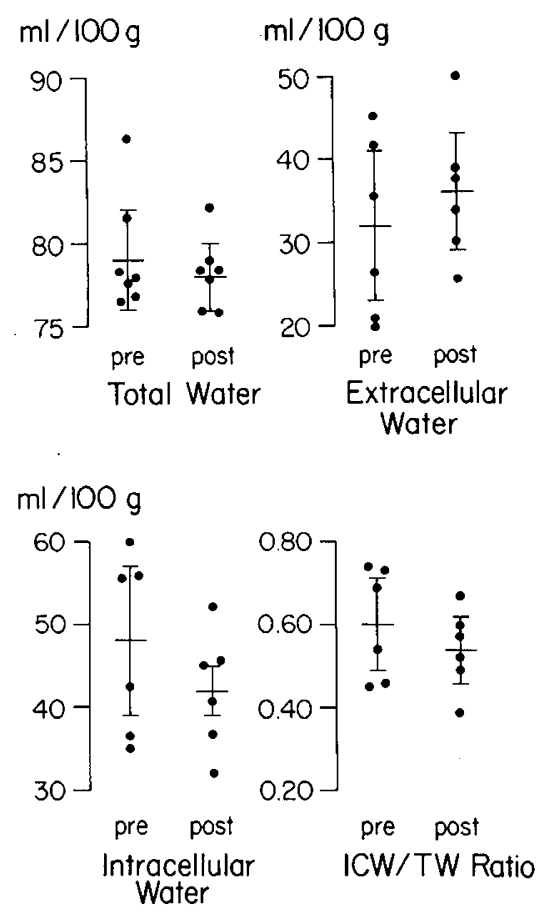

Fig. 4. Total water, extracellular water, intracellular water, and intracellular/total water ratio in pectoral muscle before and after extracorporeal circulation. Mean \pm 2 S.E. superimposed on the range of individual values.

Although plasma osmolality increased in five of eight children, the differences between pre- and postpump values were not statistically significant. Mean plasma osmolalities were $301 \pm 8.9$ and $303 \pm 5.4 \mathrm{mOsm} / \mathrm{kg}$, respectively. 


\section{DISCUSSION}

For each infant in whom body water estimates were obtained, a predicted "normal" value can be calculated according to Cheek's equations $(5,6)$. The means $( \pm$ S.D.) of observed values are compared to average predicted values in Table 3 . Compared to healthy infants and young children, infants with congenital heart disease appear to have slightly contracted total body water volumes $(662 \pm 92.9$ versus $706 \pm 12.1 \mathrm{ml} / \mathrm{kg})$ and slightly expanded volumes of extracellular water $(335 \pm 101.5$ versus $286 \pm 8.4 \mathrm{ml} /$ $\mathrm{kg}$ ) but the differences are not statistically significant. Intracellular water content, however, is significantly reduced by $24 \%$ in relation to body weight $(328 \pm 93.0$ versus $429 \pm 33.6 \mathrm{ml} / \mathrm{kg} ; P<0.001)$ and by $21 \%$ in relation to total body water (intracellular/total body water ratio: $0.48 \pm 0.133$ versus $0.61 \pm 0.021 ; P<0.001$ ) Our data differ from those of Novak and Feldt (11) who examined water compartments of five infants with congenital heart defects (11) and also compared their results to Cheek's data. They observe expansions of total extracellular and intracellular water contents in relation to body weight. Reasons for the discrepancies between the two studies are unclear. The total number of infants studied is small. Differences in dilution techniques may be responsible. We used antipyrine and bromide as markers for total and extracellular body water, respectively, whereas Novak and Feldt used deuterium and sodium, and Cheek used deuterium and bromide. Infants in Novak and Feldt's study are younger ( 3 to 5 months) than in ours, where only six of 16 are 5 months or less. Finally, differences in severity of heart disease and hemodynamic effects are difficult to assess.

Acute alterations of body water content and distribution have been reported in adults subjected to intracardiac surgery with hypothermia and extracorporeal oxygenation. Although most patients show an increase in total body water, total body water content is not statistically greater after surgery than before (12). Intracellular water content is unaffected. Extracellular water content, on the other hand, increases by a mean of 7 to $19 \%(2,12)$. These changes do not affect the extracellular compartment homogeneously: interstitial (extravascular) water increases by a mean of $12.5 \%$, whereas plasma (intravascular) volume remains unchanged (12). Data from our study suggest that infants and young children behave similarly to adults in the course of technically similar procedures. Total body water increases in most infants

Table 2. Plasma composition before and after extracorporeal circulation

\begin{tabular}{lcc}
\hline \multirow{2}{*}{\multicolumn{1}{c}{ Plasma component }} & \multicolumn{2}{c}{ Plasma concentration } \\
\cline { 2 - 3 } Sodium (mEq/liter) & $142 \pm 3.5^{1}$ & $139 \pm 2.4$ \\
Potassium (mEq/liter) & $3.3 \pm 0.16$ & $3.6 \pm 0.15$ \\
Chloride (mEq/liter) & $108 \pm 2.9^{2}$ & $100 \pm 2.0^{2}$ \\
Glucose (mg/dl) & $223 \pm 25.6^{2}$ & $283 \pm 5.3^{3}$ \\
Osmolality (mOsm/kg) & $301 \pm 8.9$ & $303 \pm 5.4$ \\
\hline
\end{tabular}

\footnotetext{
${ }^{1}$ Mean \pm S.E.

${ }^{2} P<0.002$.

${ }^{3} P<0.05$.
}

Table 3. Mean body water content observed in the study versus values predicted from normal data

\begin{tabular}{|c|c|c|c|}
\hline Body water compartment & $\begin{array}{l}\text { Observed } \\
\text { values }\end{array}$ & $\begin{array}{l}\text { Expected } \\
\text { values }\end{array}$ & $P$ \\
\hline Total body water & $662 \pm 92.9^{2}$ & $706 \pm 12.1$ & N.S. ${ }^{3}$ \\
\hline Extracellular water & $335 \pm 101.5$ & $286 \pm 8.4$ & N.S. \\
\hline Intracellular water & $328 \pm 93.0$ & $429 \pm 33.6$ & $<0.005$ \\
\hline $\begin{array}{l}\text { Intracellular/total water } \\
\text { ratio }\end{array}$ & $0.48 \pm 0.133$ & $0.61 \pm 0.021$ & $<0.005$ \\
\hline
\end{tabular}

ratio

\footnotetext{
${ }^{1}$ According to Cheek and Talbert (6) and Cheek and Graystone (5).

${ }^{2}$ Mean \pm S.D.

${ }^{3} \mathrm{NS}$, nonsignificant.
}

during surgery, but not significantly. Intracellular water content remains stable. Although the increase is not statistically significant, extracellular water does increase slightly in most patients. As in adults, extracellular water expansion is limited to the interstitial space when it increases by an average of $30 \%$ over preoperative levels and does not affect the intravascular volume. Alterations observed in adults have been blamed on retention by the body of some of the blood and diluent used to prime the extracorporeal oxygenator (2). Proposed mechanisms for such fluid retention include a decrease in plasma colloidal pressure by the diluted perfusate and an increase in capillary permeability to albumin secondary to anoxia of capillary endothelia during the procedure (12). The greater interstitial volume expansion compared to that observed in adults may be related to the technical difficulties encountered in priming the pump oxygenator with sufficiently small volumes of fluids to avoid overhydration of the patient. On the other hand, the selective effect on the interstitial space increases the likelihood of other factors playing an important role, such as more severe degrees of heart failure or the reordering of hemodynamic equilibrium after correction of a major cardiac defect.

To differentiate alterations in body composition resulting from hypothermia and extracorporeal oxygenation from those associated with the trauma of intracardiac surgery and the immediate postoperative period, water content and distribution were determined in pectoral muscle samples collected immediately before and after extracorporeal circulation. The data suggest that this procedure produced remarkably little metabolic effect at cellular level in muscle. Total muscle water content is similar before and after extracorporeal circulation. Extracellular water content increases slightly, and intracellular water content decreases slightly, but the magnitude of these changes is not significant statistically. Although there is no statistical change in the proportion of water inside the cells, the intracellular/total water ratio does decrease in five of six cases. This suggests some shift of water from the intracellular to the extracellular space occurs. This shift could well result from an osmotic attraction related to observed increases in plasma osmolality and glucose concentration. Seven of eight infants studied had plasma glucose values in the hyperglycemic range $(>125 \mathrm{mg} / \mathrm{dl}$ ) before initiation of extracorporeal circulation, and all but one had further glucose elevations in the course of the procedure. Similar data have been reported in adults who were subjected to hemodilution-perfusion primed with $5 \%$ dextrose in water and acid/citrate/dextrose blood with or without hypothermia and in children 7 to 12 years of age who underwent hemodilution-perfusion without hypothermia (14). Contrary to adults, children do not appear to respond to the increased plasma glucose by increased insulin production. Care must be taken to limit amounts of glucose infused during such operations. Plasma glucose concentration rose an average of $61 \mathrm{mg} / \mathrm{dl}$. Considering that a rise of $17.2 \mathrm{mg} / \mathrm{dl}$, increases plasma osmolality by $1 \mathrm{mOsm} / \mathrm{kg}$, $61 \mathrm{mg} / \mathrm{dl}$ would account for an osmolality increase of $3.6 \mathrm{mOsm} /$ $\mathrm{kg}$. An osmolality rise of $2 \mathrm{mOsm} / \mathrm{kg}$ was observed. Changes in extracellular fluid tonicity may well explain the tendency of water to shift from intracellular to extracellular compartment.

Whereas plasma sodium and potassium are not affected by extracorporeal circulation, chloride concentration does decrease. Postextracorporeal circulation values were observed to be an average of $7 \mathrm{mEq} /$ liter below the initial levels. This decrease presumably results from bicarbonate loading during the procedure.

These data suggest that a child's body as a whole does not react complacently to the invasive procedures associated with openheart surgery. More research into the procedures' effects on the body and into means of minimizing undesirable side effects, particularly in small children with limited homeostatic capabilities, is clearly warranted.

\section{REFERENCES AND NOTES}

1. Barratt-Boyes, B. A., Simpson, M., and Neutze, J. M.: Intracardiac surgery in neonates and infants: deep hypothermia and limited cardio-pulmonary bypass. Circulation (Suppl. I), 43-44: 25 (1971). 
2. Breckenridge. N. M., Digerness, S. B., and Kirklin, J. W.: Increased extracellular fluid after open intracardiac operation. Surg. Gynecol. Obstet., 131: 53 (1970).

3. Campbell, T. J., Frohman. B., and Reeve, E. B.: A simple, rapid, and accurate method of extracting T-1824 from plasma, adapted to the routine measurement of blood volume. J. Lab. Clin. Med., 52: 768 (1968).

4. Cassady, G.: Bromide space studies in infants of low birth weight. Pediatr. Res., 4: 20 (1970).

5. Cheek, D. B., and Graystone, J. E.: Intracellular and extracellular volume (and sodium), and exchangeable chlorides in children. In: D. B. Cheek: Human Growth: Body Composition, Cell Growth, Energy and Intelligence. pp. 150 164 (Lea and Febiger, Philadelphia, 1968).

6. Cheek, D. B., and Talbert, J. L.: Extracellular volume (and sodium) and body water in infants. In: D. B. Cheek: Human Growth: Body Composition, Cell Growth, Energy and Intelligence. pp. 117-134 (Lea and Febiger, Philadelphia, 1968).

7. Kirklin, J. W., Lell, W. A., Baxley, J. A., and Applebaum, A.: Cardiopulmonary bypass for cardiac surgery. In: D. C. Sabiston, F. C. Spencer: Gibbons Surgery of the Chest. (W. B. Saunders Company, Philadelphia, 1976).

8. Mellits, E. D., and Cheek, D. B.: Growth and body water. In: D. B. Cheek: Human Growth: Body Composition, Cell Growth, Energy and Intelligence. pp. 135-149 (Lea and Febiger, Philadelphia, 1968).

9. Mendelsohn, D., and Levin, N. W.: A colorimetric micromethod for the estimation of antipyrine in plasma and serum. S. Afr. J. Med. Sci., 25: 13 (1960).

10. Nelson, W. E., Vaughan, V. C., and McKay, R. J. [eds.]: Textbook of Pediatrics. p. 40 (W. B. Saunders Company, Philadelphia, 1969).

11. Novak, L. P., and Feldt, R. H.: Body fluids and electrolytes in infants and children with congenital heart disease. Mayo Clin. Proc., 47: 327 (1972).

12. Pacifico, A. D., Digerness, S., and Kirklin, J. W.: Acute alteration of body composition after open intracardiac operations. Circulation, 41: 331 (1970).

13. Parr, G. V. S., Blackstone, E. H., and Kirklin, J. W.: Cardiac performance and mortality early after cardiac surgery in infants and young children. Circulation, 51: 867 (1975).

14. Stremmel, W., Schlosser, V., and Koehnlein, H. E.: Effect of open-heart surgery with hemodilution perfusion upon insulin secretion. J. Thorac. Cardiovasc. Surg., 64: 263 (1972).

15. Wolf, R. L., and Eddie, G. S.: Reabsorption of bromide by the kidney. Am. J. Physiol., 163: 436 (1939).

16. Vitarine Company, Springfield Gardens, NY.

17. Bentley Laboratories, Irvine, CA.

18. Allied Chemical General Chemical Division, New York, NY.

19. Merck and Company, Rahway, NJ.

20. Harvey Laboratories, Philadelphia, PA.

21. Nuclear Chicago, Fort Lee, NJ.

22. Requests for reprints should be addressed to: Yves W. Brans, M.D., Department of Pediatrics, University of Texas Health Science Center, 7703 Floyd Curl Drive, San Antonio, Texas 78284 (USA).

23. Received for publication July 15,1980

24. Accepted for publication November 6, 1980. 